\title{
Evaluation of reliability of solubility in potassium hydroxide solution as an in vitro method for predicting organic matter digestibility of ruminant feeds
}

\author{
Anna M. Antoniewicz', J. De Boever ${ }^{2}$, F. Brzóska ${ }^{3}$, R. Ostrowski ${ }^{4}$, \\ B. Marek ${ }^{1}$
}

'Department of Animal Nutrition and Physiology, Research Institute of Animal Production Sarego 2, 31-047 Kraków, Poland

${ }^{2}$ National Institute for Animal Nutrition

Scheldeweg 68, B-9090 Melle-Gontrode, Belgium

${ }^{3}$ Department of Feed Science and Animal Products,

Research Institute of Animal Production, 32-083 Balice, Poland

${ }^{4}$ Research Institute of Animal Production, Experimental Station Pawlowice, 64-122 P'awlowice, Poland

(Received 1 October 1995; accepted 12 January 1996)

\begin{abstract}
The applicability of the alkaline extraction method using a $5 \%$ potassium hydroxide (KOH) solution to predict organic matter digestibility (DOM) of ruminant fceds was cxamined. The predictive value of the assay was estimated using 110 feeds including dried grass (70), grass silages (33) and compounds (7) of known DOM determined on sheep $\left(\mathrm{DOM}_{\mathrm{v}}\right)$.

A fairly close linear relationships for all samples and forages between the in vilro organic matter digestibility $\left(\mathrm{DOM}_{\mathrm{k}}, \mathrm{X}, \%\right)$ and $\mathrm{DOM}_{\mathrm{v}}(\mathrm{Y}, \%)$ estimates were found. The regression equation for all samples $(\mathrm{n}=110)$ was $\mathrm{Y}=0.934 \mathrm{X}+5.74, \mathrm{R}^{2}=0.75(\mathrm{P}<0.001)$, residual standard deviation $\mathrm{RSD}$ 3.65 , for all forages $(n=103) Y=0.903 X+7.67, R^{2}=0.67(P<0.001)$, RSD 3.62. The regression of $\mathrm{DOM}_{v}$ on $\mathrm{DOM}_{k}$ for compounds $(n=7)$ was insignificant $\left(\mathrm{R}^{2}=0.30\right.$, RSD 3.74).

The relationship between $\mathrm{DOM}_{\mathrm{y}}$ (determined values) and $\mathrm{DOM}_{\mathrm{vk}}$ (predicted from the equation for all samples) was linear. The predicted values could account for $75 \%$ of the variance in determined

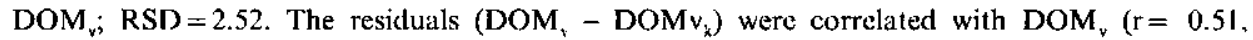
$\mathrm{P}<0.001$ ). $\mathrm{DOM}_{\mathrm{vk}}$ tended to be overestimated for samples of DOM ranging $50-60 \%$ (negative residuals only) and underestimated for that of DOM exceeding $80 \%$ (positive residuals only). The most even distribution of the residuals was in the DOM range of $70-80 \%$.
\end{abstract}

KEY WORDS: feeds, organic matter, in vitro digestibility, alkaline extraction, potassium hydroxide 


\section{INTRODUCTION}

The content of digestible nutrients, particularly organic matter digestibility (DOM) is one of the main determinants of the metabolizable energy (ME) value of ruminant feeds. The DOM may be accurately determined in vivo on sheep in balance trials, providing the reliability of animals has been tested beforehand (Daccord and Schneeberger, 1986). However, such trials are costly, considering the maintenance and careful selection of animals as well as feed, labor and time consumption. Therefore, for routine feed examination, particularly in comparing the quality of varicties and maturity stages of plants, or different batches of concentrate ingredients etc. various in vitro methods have been developed. Also several models have been designed to calculate DOM and ME of feeds from their chemical composition (Weiss et al., 1992).

Most in vitro methods simulate, to some extent, gut digestion, because feeds are incubated with buffered rumen fluid or/and different enzyme systems (Tilley and Terry, 1963; Kirchgessner and Kellner, 1978; McLeod and Minson, 1982). A very simple method, based on solubilization of feed while boiled with a $\mathrm{KOH}$ solution was proposed by Kesting (1978). The method proved more accurate than incubation with cellulase for the prediction of DOM of dried grass and red clover in the work of Kosmala and Brzóska (1982). However, Vencl and Flam (1981) found that laboratory estimates of in vivo DOM were better using a two-stage method of Tilley and Terry (1963) than extraction with $5 \% \mathrm{KOH}$ according to Kesting (1978).

Considering the simplicity and potential applicability of the method of Kesting (1978) for routine screening of DOM of ruminant feeds, further evaluation of this method seemed advisable. This paper shows the results of examining the accuracy of predicting DOM of hays, grass silages and compound feeds of known DOM determined in vivo on sheep.

\section{MATERIAL AND METHODS}

\section{Feeds}

Feed samples of known DOM determined in vivo $\left(\mathrm{DOM}_{\mathrm{v}}\right)$ on sheep were obtained from three laboratories in the Institute of Animal Production in Melle-Gontrode (Belgium), and the Research Institute of Animal Production in Poland. The type and number of feeds and their protein and fibre contents are given in Table 1. 
TABLE 1

Description of samples used in evaluation of $\mathrm{KOH}$ extraction procedure

\begin{tabular}{|c|c|c|c|c|c|c|c|}
\hline \multirow[b]{2}{*}{ Sample } & \multirow[b]{2}{*}{$n$} & \multicolumn{2}{|c|}{ Crude protein } & \multicolumn{2}{|c|}{ Crude fibre $(\mathrm{g} / \mathrm{kg}$ DM) } & \multicolumn{2}{|c|}{ NDF } \\
\hline & & Min & $\operatorname{Max}$ & Min & $\operatorname{Max}$ & Min & Max \\
\hline All samples & 110 & 74 & 233 & & & & \\
\hline Dried grass & 70 & 74 & 198 & 206 & 425 & & \\
\hline Grass silages & 33 & 90 & 208 & 193 & 393 & & \\
\hline Compounds & 7 & 162 & 233 & & & 155 & 301 \\
\hline
\end{tabular}

In vitro analysis

Extraction of feeds with potassium hydroxide solution (5\%) according to the Kesting (1978) procedure was conducted using a Fibretec M6 apparatus (Tecator, Sweden). The residues were ashed at $600^{\circ} \mathrm{C}$.

\section{Statistical analysis}

The values of OM digestibility of samples used for validation of the chemical method were evaluated as to their distribution around the centroid (a mean point in the multidimensional space) using Mahalonobis distances $(\mathrm{H})$, in order to define outliers in the population (Shenk and Westerhaus, 1991).

The results of DOM $\mathrm{v}$ and that obtained by the chemical method $\left(\mathrm{DOM}_{\mathrm{k}}\right)$ were subjected to analysis of variance and the relationship between the in vivo and in vitro values was evaluated using linear regression and correlation coefficients. The regression equations of DOMv in relation to DOMk were calculated for all samples and separately for specific groups, e.g. all forages, dried grass, grass silages and compounds. The predictive ability of the regression equations was characterized by standard errors of $b$ (SE) and residual standard deviations (RSD) which werc calculated as a measure of variation in $\mathrm{DOM}_{\mathrm{v}}$ that could not be accounted for by the differences in $\mathrm{DOM}_{k}$. The values of $\mathrm{DOM}$ in vivo predicted basect on in vitro observations and the regression equation $\left(\mathrm{DOM}_{\mathrm{vk}}\right)$ were compared to $\mathrm{DOM}_{\mathrm{v}}$ values using linear regression. The distribution of residuals i.e. the determined minus predicted values, in relation to the determined $\mathrm{DOM}_{\mathrm{v}}$ was analysed. All calculations and analyses were done using Microsoft Statistica ${ }^{k}$ software.

\section{RESLLTS}

The distribution of Mahalanobis distances $(\mathrm{H})$ in comparison with the expected normal distribution is shown in Figure 1. Most of the samples fit the 


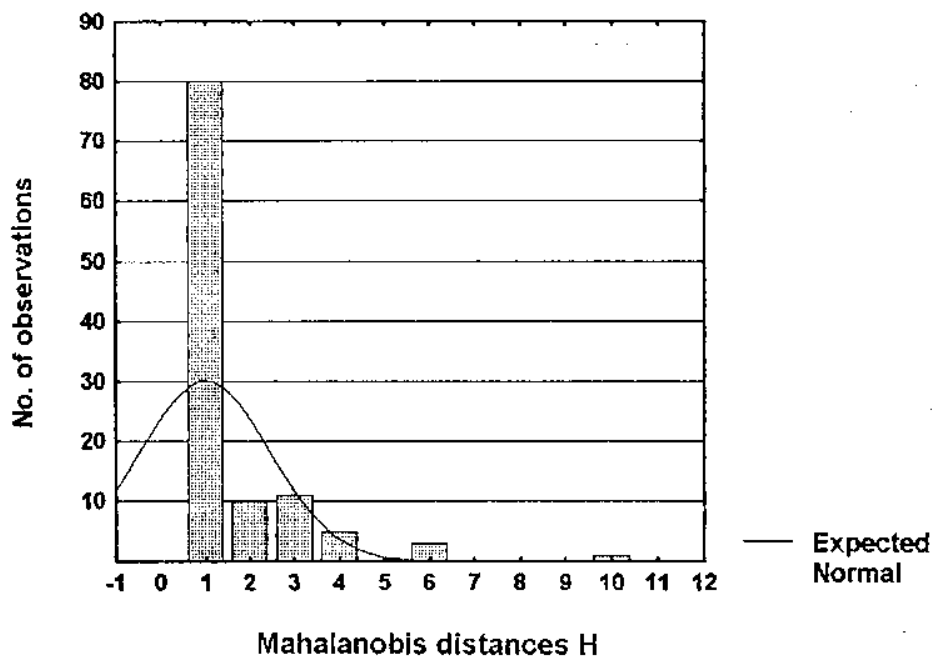

Figure 1. The distribution of Mahalanobis distances $\mathrm{H}$ in the values of in vivo organic matter digestibility $\mathrm{DOM}_{\psi}$ of 110 feed samples (observations); $I \mathbf{I}>3$ indicates structural outliers

within maximum of normal distribution. Out of 110 , only 9 samples -4 hays of relatively low $\operatorname{DOM}_{\mathrm{v}}(56-64 \%), 4$ compounds and 1 silage of extremely high $\operatorname{DOM}_{v}(82.6 \%)$ were characterized by $\mathrm{H}>3$ and could be considered as structural outliers.

The descriptive statistics for the $\mathrm{DOM}_{\mathrm{v}}$ and $\mathrm{DOM}_{\mathrm{k}}$ values are given in Table 2 . The means and ranges of the values from both in vivo and in vitro methods were similar - differences ranged from 0.6 to $3.5 \%$. However, standard deviations in the $\mathrm{DOM}_{\mathrm{k}}$ values were slightly lower, which may be a consequence of either lower sensitivity of the in vitro method or a higher error on in vivo estimates.

TABI.E 2

Descriptive statistics of the digestible organic matter content determined in sheep $\left(\mathrm{DOM}_{v}\right)$ and using $\mathrm{KOH}$ extraction $\left(\mathrm{DOM}_{\mathrm{k}}\right)$

\begin{tabular}{llccccc}
\hline $\begin{array}{l}\text { Sample } \\
\text { Variable }\end{array}$ & $\mathrm{n}$ & Mean & Min & Max & SD $^{a}$ & g/kg OM \\
\hline All samples & DOM $_{\mathrm{v}}$ & 110 & 705 & 548 & 887 & 71.9 \\
& DOM $_{\mathrm{k}}$ & 110 & 694 & 545 & 898 & 66.6 \\
Dricd grass & DOM $_{\mathrm{v}}$ & 70 & 674 & 548 & 801 & 61.0 \\
& DOM $_{\mathrm{k}}$ & 70 & 661 & 545 & 791 & 59.0 \\
Grass silagcs & DOM $_{\mathrm{v}}$ & 33 & 741 & 658 & 826 & 37.3 \\
& DOM $_{\mathrm{k}}$ & 33 & 736 & 660 & 813 & 32.7 \\
Compounds & DOM $_{\mathrm{v}}$ & 7 & 849 & 763 & 887 & 40.9 \\
& DOM $_{\mathrm{k}}$ & 7 & 829 & 790 & 898 & 37.2 \\
\hline
\end{tabular}

${ }^{\mathrm{a} S D}$ - standard deviation 
TABLE 3

Statistical parameters of lincar regression between digestibility of organic matter determined in vivo on sheep $(\mathrm{Y}, \%)$ and in vitro by solubility in $\mathrm{KOH}$ solution $(\mathrm{X}, \%)$; model $\mathrm{Y}=\mathrm{a}+\mathrm{bX}$

\begin{tabular}{lrrrrccc}
\hline Sample & $\mathrm{n}$ & $R^{2}$ & $\mathrm{RSI})^{\mathrm{a}}$ & $\mathrm{a}$ & $\mathrm{b}$ & $\mathrm{SE}^{\mathrm{h}}$ of $\mathrm{b}$ & significance of $\mathrm{b}$ \\
\hline All samples & 110 & 0.75 & 3.65 & 5.74 & 0.934 & 0.053 & $\mathrm{P}<0.001$ \\
Dried grass & 70 & 0.61 & 4.02 & 7.91 & 0.901 & 0.096 & $\mathrm{P}<0.001$ \\
Grass silages & 33 & 0.53 & 2.59 & 12.96 & 0.831 & 0.140 & $\mathrm{P}<0.001$ \\
Compounds & 7 & 0.30 & 3.74 & 34.88 & 0.603 & 0.410 & $\mathbf{P}=0.20$ \\
\hline
\end{tabular}

${ }^{\text {a } R S D ~-~ r e s i d u a l ~ s t a n d a r d ~ d e v i a t i o n ~}$

'SE: - standard crror

The regression equations between $\mathrm{DOM}_{\mathrm{v}}(\mathrm{Y}, \%)$ and $\mathrm{DOM}_{k}(\mathrm{X}, \%)$ for the combined and individual groups of samples are given in Table 3 . The relationship was significant $(\mathrm{P}<0.001)$ for the combined set of samples $(\mathrm{r}=0.86, \mathrm{n}=110)$, all forages $(r=0.82, n=103)$, dried grass $(r=0.75, n=70)$ and grass silages $(r=$ $0.73, \mathrm{n}=33)$. However, the relationship was insignificant $(\mathrm{r}=0.55, \mathrm{P}=0.2)$ for compounds, due to either the low number of feeds evaluated $(n=7)$ or the relatively narrow range of $\mathrm{DOM}_{k}$ values what made it impossible to determine coefficient $b$ with high accuracy. The regression of $\mathbf{D O M}_{\mathrm{y}}$ on $\mathbf{D O M}_{k}$ explained from 30 to $75 \%$ of total variation in the organic matter digestibility of various feed categories determined in vivo.

The rclationship between $\mathrm{DOM}_{\mathrm{v}}(\mathrm{Y}, \%)$ and $\mathrm{DOM}_{\mathrm{k}}(\mathrm{X}, \%)$ values is presented in Figure 2. All samples, regardless of their nature and origin appear to fit the

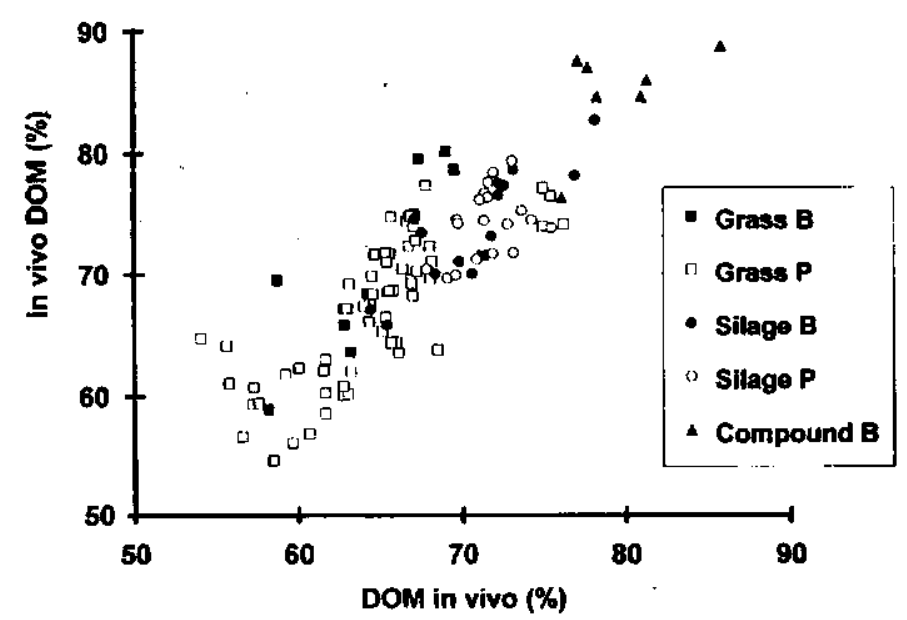

Figure 2. The relationship between the digestibility of organic matter in vivo ( $\mathrm{Y})$ and in vitro $(\mathrm{X})$ for 110 feed samples: $Y=0.934 X+5.47, R^{2} 0.75$, RSD 3.65, $P<0.001$. In the legend $B$ indicatcs samples from Belgium, $P$ from Poland 


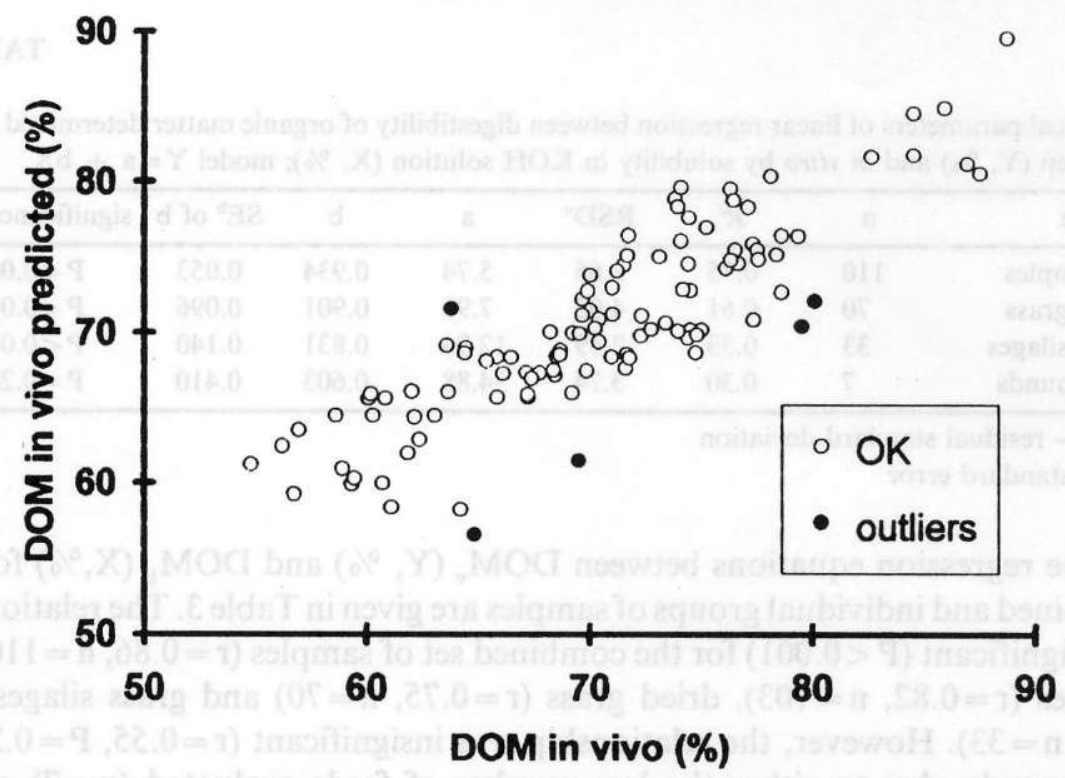

Figure 3. The relationship between the digestibility of organic matter (DOM) in vivo $\mathrm{DOM}_{\mathrm{v}}$ determined on sheep (observed) and predicted from DOM in vitro based on the relationship: $\mathrm{Y}=0.934 \mathrm{X}+5.47\left(\mathrm{DOM}_{\mathrm{vk}}\right)$. Open circles indicate samples having residuals within the range \pm 2 sigma; closed circles indicate outliers (residuals beyond the range \pm 2 sigma)

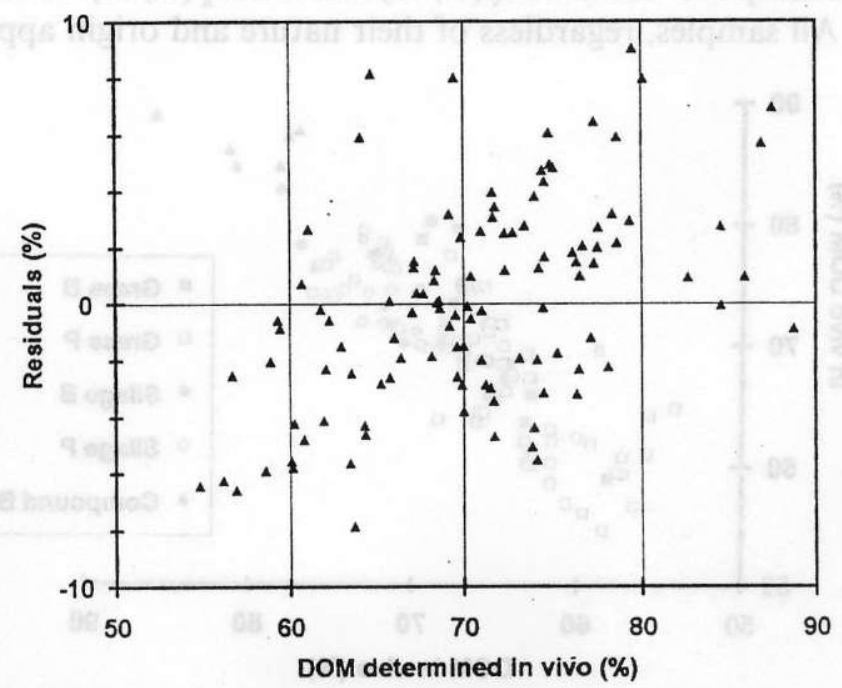

Figure 4. The relationship between the residuals i.e. $\left(\mathrm{DOM}_{\mathrm{v}}-\mathrm{DOM}_{\mathrm{vk}}\right)$ and $\mathrm{DOM}_{\mathrm{v}}: \mathrm{r}=0.51, \mathrm{P}<0.001$. $\mathrm{DOM}_{\mathrm{v}}$ denotes the digestibility of organic matter (DOM) determined on sheep; $\mathrm{DOM}_{\mathrm{vk}}$ denotes DOM predicted from DOM in vitro $(\mathrm{X})$ based on equation $\mathrm{Y}=0.934 \mathrm{X}+5.47$ 
same cquation relatively well (Table 3): $\mathrm{Y}=0.934 \mathrm{X}+5.74$, standard error of $b \mathrm{SE}_{b}=0.05$, significance of coefficient $a \mathrm{P}=0.05, \mathrm{SE}_{a}=3.74$.

The relationship between $\mathrm{DOM}_{\mathrm{v}}$ (determined values) and $\mathrm{DOM}_{\mathrm{vk}}$ (predicted from the equation for all samples) is shown in Figure 3. The predicted values could account for $75 \%$ of variance in determined $\mathrm{DOM}_{\mathrm{v}} ; \mathrm{RSD}=2.52 \%$. There were only 5 outliers, defined by residuals $>+2$ sigma, actually having the residuals higher than 7.8 .

Analysis of residuals $\left(\mathrm{DOM}_{\mathrm{v}}-\mathrm{DOM}_{\mathrm{vk}}\right)$ in relation to the $\mathrm{DOM}_{\mathrm{v}}$ is shown in Figure 4. The residuals were correlated with $\operatorname{DOM}_{v}(r=0.51, P<0.001)$. It may be seen from the scatterplot that $\mathrm{DOM}_{\mathrm{vk}}$ values tend to be overestimated for samples of DOM ranging between $50-60 \%$ (negative residuals only) and underestimated for those exceeding $80 \%$ (positive residuals only). The most even distribution of the residuals was in the DOM range of $70-80 \%$.

\section{DISCUSSION}

The distribution of $\mathrm{H}$ values revealed that about $80 \%$ of samples are centered around $H=1$. According to Shenk and Westerhaus (1991), probably part of these samples could have been eliminated from calculation of the regression equation for DOM prediction without significant loss of accuracy. However, our set was at least 10 times less numerous than the set they used for nutrient content prediction by near infrared spectroscopy. Therefore, any of these samples was eliminated. Neither data for the identified outliers (showing $\mathrm{H}>3$ ) removed from the calculation of the regression of $\mathrm{DOM}_{\mathrm{v}}$ on $\mathrm{DOM}_{\mathrm{k}}$, in order to obtain a robust prediction equation.

In our study, the extraction with boiling $\mathrm{KOH}$ solution could account for $75 \%$ of the variability in DOM of 110 samples in wide range with a $\mathrm{CP}$ and $\mathrm{CF}$ content (RSD 2.6-4.0). The relationship was definitely poorer than that showed by Kesting (1978) who indicated the method could account for $88 \%$ of variation in DOM in 109 samples including forages and concentrates. However, the prediction in our study was better than found by Vencl and Flam (1981): $R^{2}=17 \%, \mathrm{n}=56$. The latter authors showed a relatively good in vivo-in vitro relationship for maize silage $\left(R^{2}=58 \%, \mathrm{n}=7\right)$ and pelleted forages $\left(R^{2}=74 \%\right.$, $\mathrm{n}=8$ ). In contrast to the results of Kesting (1978) and that found in the present study, Vencl and Flam (1981) were not able to predict $\mathrm{DOM}_{\mathrm{v}}$ of various samples using the same equation. However, the total number of samples used by the latter authors was only half of that used in our study and in the work of Kesting (1978).

$\mathrm{DOM}_{\mathrm{v}}$ of ruminant feeds, particularly forages, can be precisely predicted by the rumen inoculum-pepsin method of Tilley and Terry (1963). In the study of Vencl and Flam (1981), this method proved slightly better than the alkaline 
extraction in the prediction of $\operatorname{DOM}_{\mathrm{v}}\left(R^{2}=31,55\right.$ and $83 \%$, respectively, for all 56 feeds, hays and silage samples). Kosmala and Brzóska (1982) comparing in vitro methods using $\mathrm{KOH}$, cellulase or rumen fluid to predict $\mathrm{DOM}_{\mathrm{v}}$ of grass and clover forage $(n=17)$ found the best results with the chemical method $(r=0.74)$. Narasimhalu (1985) also compared the rumen inoculum-pepsin method (Tilley and Terry, 1963) with various cellulase procedures and found that the coefficients of determination in the prediction of DM digestibility were 75 and $24-58 \%$, respectively. In case of using a two-stage cellulase procedure, the variation accounted for by the regression increased from 24 to $69 \%$ when lignin content was included as the second independent variable in the prediction equation (Narasimhalu, 1985).

Essentially, the results of enzymatic methods using fungal cellulases depended on the kind of samples evaluated and procedure used. In most experiments, the coefficients of determination $R^{2}$ for forages (dried grass and legumes, silages) ranged from 50 to $72-88 \%$ and RSDs were between 2 and 4 digestibility percentage units (Dowman and Collins, 1977; McLeod and Minson, 1982; Valdes and Jones, 1987). Thus, the accuracy of the enzymatic method was not always better than that of the alkaline extraction shown in the present study. The results of the latter method are also better than those obtained using the technique of gas production during incubation with buffered rumen fluid: $R^{2}$ 72\%, RSD 2.4-7.9 depending on sample set (Menke and Steingass, 1987).

The method of alkaline extraction has an advantage compared with methods using different inocula: its conditions are very standarized so that it is not necessary to analyze standard feeds in each series to allow for the changes in cellulolytic activity of the incubation medium. However, the method is very unspecific.

In feed evaluation laboratories that do not keep cannulated animals as donors of rumen fluid, the $\mathrm{KOH}$ method or enzymatic techniques may be used. Fungal cellulases resemble to some extent the action of ruminal cellulolytic enzymes and therefore the enzymatic methods seem more specific. However, considering its simplicity and very low cost of reagents, and taking into account a small RSD, the method using the alkaline extraction may be used in comparative works. It may introduce systematic errors as far as the feeds of DOM $<60 \%$ and of DOM $>80 \%$ are concerned. Its accuracy could probably be improved by adding lignin as a second independent variable in the regression.

\section{CONCLUSIONS}

The measurement of organic matter digestibility by extracion with boiling $5 \%$ $\mathrm{KOH}$ solution is a cheap, simple, rapid and fairly accurate procedure to evaluate 
ruminant feeds. More research is needed to improve the accuracy of the method by introducing further independent variable (i.e. lignin) to the regression equation.

\section{REFERENCES}

Daccord R., Schneeberger H., 1986. Variability and repcatability of digestibility evaluated on sheep. J. Anim. Physiol. Anim. Nutr. 56, 35-41

Dowman M.G., Collins F.C., 1977. The prediction of the digestibility of silages using cellulase. J. Sci. Food Agric. 28, 1071-1074

Kesting U., 1978. Ueber neuerc Ergcbnisse cincr vercinfachten in-vitro-Mcthode zur Schaetzung der Verdaulichkeit der organischen Substanz ohne Pansensaft. 1. Dic Bezichungen zwischen Kaliumhydroxid-Loeslichkeit und der Verdaulichkeit der organischen Substanz von Grobfutterstoffen und Konzentraten. Arch. Tierernähr. 28, 491-497

Kirchgessner M., Kellner R.J., 1978. Estimation of digestibility, metabolizable energy and net energy of forage by a cellulase method. Livest. Prod. Sci. 5, 373-377

Kosmala I., Brzóska F.,1982. Comparison of digestibility of roughages estimated by laboratory methods in vitro and in vivo (in Polish). Rocz. Nauk. Zoot. 9, 89-97

McLeod M.N., Minson D.J., 1982. The analytical and biological accuracy of estimating the dry matter digestibility of different legume species. Anim. Feed Sci. Technol. 1, 61-72

Menke K.H., Steingass H., 1987. Schaetzung des Energetischen Futterwerts aus der in vitro mit Pansensaft bestimmten Gasbildung und der chemischen Analyse. II. Regressiongleichungen. bers. Ticrernähr. 15, 59-94

Narasimhalu P., 1985. A comparison of laboratory methods involving single or two-stage cellulase and two-stage rumen inoculum-pepsin treatment for predicting digestibility and intake of hays in sheep. Anim. Feed Sci. Technol. 12, 101-107

Shenk J.S.. Westerhaus M.O., 1991. Population structuring of near infrared spectra and modificd partial least squares regression. Crop. Sci. 31, 1548-1555

Tilley J.M.A., Terry R.A., 1963. A two-stage technique for the in vitro digestion of forage crops. J. Br. Grassld. Soc. 18, 104-111

Valdes E.V., Jones G.E., 1987. A comparison of in vitro and in vivo dry matter digestibility techniques for the cvaluation of forage quality. Can. J. Anim. Sci. 67, 573-576

Vencl B., Flam F., 1981. Predicting the energetic value of forage from digestibility of organic matter in vitro or solubility in potassium hydroxide. Anim. Feed Sci. Technol. 6, 235-243

Weiss W.P., Conrad H.R., Picrre N.R.St., 1992. A theoretically-based modcl for predicting total digestible nutrient values of forages and concentrates. Anim. Feed Sci. Technol. 39, 95-110

\section{STRESZCZENIE}

Ocena przydatıości rozpuszczalności $w$ roztworze wodorotlenku potasu jako metody in vitro szacowania strawności masy organicznej pasz dla przeżuwaczy

Badano przydatność metody ekstrakcji przy pomocy $5 \%$ roztworu wodorotlenku potasu (KOH) do szacowania strawności masy organicznej (DOM) pasz đla przeżuwaczy. Zdolność predykcyjną 
metody oceniano dla 110 pasz, w tym: suszone trawy (70), kiszonki z traw (33) i mieszanki treściwe (7) 0 znancj DOM oznaczoncj na owcach $\left(\right.$ DOM $\left._{v}\right)$.

Stwierdzono dość ścisłą zależność pomiędzy strawnością masy organicznej in vitro $\mathrm{DOM}_{\mathrm{k}}(\mathrm{X}, \%)$ i $\operatorname{DOM}_{v}(\mathrm{Y}, \%)$ przy porównywanju danych dla wszystkich prób i pasz objętościowych. Równania regresji wynosiły: dla wszystkich prób $(\mathrm{n}=110) \mathrm{Y}=0,934 \mathrm{X}+5,74, R^{2}=0,75(\mathrm{P}<0,001)$, błąd szacowania RSD 3,65; dia pas\% objętościowych $(\mathrm{n}=103) \mathrm{Y}=0,903 \mathrm{X}+7,67, R^{2}=0,67(\mathrm{P}<0,001)$, RSD 3,62. Regresja $\mathrm{DOM}_{v}$ względem $\mathrm{DOM}_{\mathrm{k}}$ dla mieszanek treściwych $(\mathrm{n}=7)$ była nieistotna $\left(R^{2}=0,30\right.$, RSI) 3,74).

Stwierdzono liniową zależność pomiędzy DOM $_{\mathrm{v}}$ (wartości zmicrzone) i DOM $\mathrm{k}$ (szacowane na podstawie równania dla wszystkich prób). Wartości szacowane pozwalały na przewidywanie do $75 \%$ zmienności stwierdzonej w DOM ${ }_{v}$ RSD 2,52. Różnice DOM $_{v}-$ DOM $_{v} \mathrm{k}$ byly skorelowane z DOM $(\mathrm{r}=0,51, \mathrm{P}<0,001)$. Ujawnila się tendencja do szacowania wartości $\mathrm{DOM}_{\mathrm{v}} \mathrm{k}$ za wysoko przy $\mathrm{DOM}_{\mathrm{v}}$ w zakresic $50-60 \%$ (różnice <0) i za nisko przy $\mathrm{DOM}_{v}>80 \%$ (różnice $>0$ ). Najbardziej równomierny rozkład różnic obserwowano w zakresie $\mathrm{DOM}_{v} 70-80 \%$. 